\title{
STRATEGI PROMOSI DALAM MENINGKATKAN JUMLAH MAHASISWA PADA PERGURUAN TINGGI
}

\author{
${ }^{1}$ Renata dan ${ }^{2}$ Tobari \\ ${ }^{1}$ Peneliti dan Praktisi Pendidikan Kota Palembang \\ ${ }^{2}$ Dosen Program Studi Magister Manajemen Pendidikan, Universitas PGRI Palembang \\ e-mail: renatagunanta1@gmail.com
}

\begin{abstract}
Currently, happened the competition of universities both state (PTN) and private (PTS) in Indonesia for gaining students. This study aimed at analyzing the promotional strategies, effectiveness, and inhibiting factors of promotion by using mixed method. Subjects in this study consisted of promotion team and prospective new students in PGRI University of Palembang as many as 53 people. Data were collected through interview and questionnaire, then analyzed by using data triangulation technique and regression test technique. The results showed that the promotion strategy undertaken by PGRI University of Palembang was Advertising, Personal Selling, Publicity, and Word of Mouth. Partial advertisement is the most influential variable (34,4\%) whereas the least influence variable was Publicity (19,3\%). Advertising Variables, Personal Selling, Publicity, and Word of Mouth simultaneously have a significant effect on the increase of the students by $65.6 \%$ while the remaining $34.4 \%$ was influenced by other variables. The inhibiting factors of promotional activities were insufficient promotional funds, lack of human resources in the field of communication science, as well as interpersonal communication that is less harmonic among employees.
\end{abstract}

Keywords: Promotional Strategies; the Increase of the Students, PGRI Univerity of Palembang

\section{PENDAHULUAN}

Perguruan tinggi adalah suatu wadah yang digunakan sebagai Research and Development serta arena pembentukan manusia baru untuk menghasilkan generasi yang memiliki kepribadian serta kompetensi keilmuan sesuai bidangnya (Sutabri, 2007). Saat ini, apabila seseorang memasuki perguruan tinggi maka orang tersebut membeli jasa pendidikan tinggi. Keputusan memilih suatu perguruan tinggi merupakan suatu keputusan investasi. Investasi tersebut harus menguntungkan konsumen setelah dinyatakan tamat dari perguruan tinggi. Hal tersebut dikarenakan selain membutuhkan biaya yang besar, kuliah di perguruan tinggi juga menghabiskan waktu yang cukup lama. Oleh karena itu, konsumen perguruan tinggi harus memiliki strategi dalam memilih suatu perguruan tinggi yang baik dan berkualitas.

Persaingan pada industri pendidikan tinggi dalam memperebutkan pasar mahasiswa sudah mulai semakin ketat. Hal ini ditambah lagi dengan perguruan tinggi swasta di Indonesia yang saat ini sudah tumbuh subur bagai "jamur di musim hujan". Dengan kondisi tersebut, bagi perguruan tinggi yang baru terbentuk dan belum begitu dikenal merasakan dampak hebatnya persaingan dalam mendapatkan mahasiswa. Menurut Lupiyoadi (2001), alasan lain yang menyebabkan persaingan industri pendidikan tinggi semakin 
ketat adalah adanya Peraturan Pemerintah Nomor 61 Tahun1999 tentang Otonomi Perguruan Tinggi. Melalui PP tersebut, pemerintah memberikan kesempatan kepada setiap Perguruan Tinggi (PT) untuk melahirkan manajemen yang lebih efisien dan berdampak pada pengembangan keilmuan lewat otonomi Perguruan Tinggi. Selain itu, Perguruan Tinggi Swasta juga diberi kesempatan untuk tumbuh dan berkembang sejajar dengan Perguruan Tinggi Negeri.

Untuk mengatasi hal tersebut, penyelenggara pendidikan tinggi perlu mengelola organisasinya seperti layaknya suatu bisnis dengan tidak meninggalkan aspek idealnya. Konsep pemasaran harus diterapkan dalam mengelola organisasi. Pemasaran bukan lagi merupakan aktivitas fungsional bagian pemasaran saja melainkan merupakan bagian yang utuh dari suatu organisasi. Perusahaan harus mampu untuk mentransformasi dirinya menjadi the marketing company untuk bersaing secara global. Kunci penting dalam pemasaran adalah komunikasi yang efektif, dimana pesan-pesan dikonstruksi berdasarkan tujuan yang diharapkan. Penyusunan (konstruksi) pesan ini tidak bisa melupakan segmentasi pasar yang ingin diraih. Instrumen dasar yang digunakan untuk mencapai tujuan komunikasi suatu perusahaan atau organisasi adalah strategi promosi yang efektif dengan mengacu kepada bauran promosi (promotion mix).

Universitas PGRI Palembang sebagai pengembangan dari Sekolah Tinggi Keguruan dan Ilmu Pendidikan (STKIP) yang mendapat izin dengan Sk Mendiknas No. 97/D/O/2000 tanggal 9 Juni 2000, berdiri 5 fakultas dan 1 Pascasarjana yaitu: fakultas keguruan dan ilmu pendidikan, fakultas ekonomi, fakultas teknik, fakultas perikanana dan pascasarjana. Melihat usia dan ciri pendidikan pada Universitas PGRI Palembang yang masih baru dan belum begitu dikenal oleh masyarakat khususnya di kota Palembang, maka sangat perlu memperkenalkan dan memasarkan lembaga pendidikan tinggi ini secara lebih luas kepada masyarakat khususnya calon mahasiswa. Selain itu dari hasil wawancara awal dengan humas dan tim promosi Universitas PGRI Palembang, saat ini posisi Universitas PGRI Palembang masih belum menjadi pilihan utama apabila dibandingkan dengan Perguruan Tinggi lain yang telah lebih dahulu berdiri. Untuk mengatasi persaingan ketat tersebut, menurut tim promosi Universitas PGRI Palembang telah membuat berbagai macam strategi promosi, seperti periklanan, penjualan produk perorangan, publisitas, dan word of mouth. Akan tetapi strategi promosi diatas belum mampu memberikan hasil sesuai dengan yang diinginkan. Penelitian ini dilakukan kepada calon mahasiswa TA. 2014- 
2015, tahun ajaran ini dipilih karena dari hasil data awal yang didapatkan menunjukkan bauran promosi yang digunakan lebih baru dan beragam.

Tujuan umum penelitian ini adalah untuk menganalisis strategi promosi, efektifitas, dan faktor penghambat promosi dengan menggunakan metode campuran (mixed method).

\section{METODE PENELITIAN}

Penelitian ini dilaksanakan di kantor Universitas PGRI Palembang. Berdasarkan tujuan penelitiannya maka peneliti menggunakan purposive sample (sampel bertujuan). Menurut Yuliani dan Kristiawan (2017) purposive sample berarti peneliti memilih sampel berdasarkan pengalamannya atau pengetahuan dari kelompok untuk menjadi sampel. Oleh karena itu, informan yang peneliti anggap relevan dan sesuai dengan tujuan penelitian ini, yaitu Tim Promosi (tenaga struktural dan fungsional yang terlibat) Universitas PGRI Palembang, calon mahasiswa baru tahun 2014 yang mendaftar dan melakukan registrasi ulang pada Universitas PGRI Palembang. Metode sampling untuk mahasiswa adalah rancangan sampel probalitas (probality sampling design) dengan teknik sampel acak sederhana (simple random sampling).
Tahap berikutnya adalah penentuan besaran jumlah sampel responden yang tersedia dipilih dengan menggunakan menggunakan rumus Slovin (dalam Bungin, 2013), Rumusnya adalah:

dengan rumus :

$$
\begin{aligned}
& \mathrm{n}= \\
& \mathrm{n}=\text { ukuran sampel } \\
& \mathrm{N}=\text { ukuran populasi } \\
& \mathrm{E}=\text { persentase kelonggaran ketidak } \\
& \quad \text { telitian karena kesalahan } \\
& \quad \text { pengambilan sampel yang } \\
& \quad \text { ditolerir dimana ditetapkan } 5 \% .
\end{aligned}
$$

Berdasarkan jumlah populasi calon mahasiswa tahun ajaran 2014-2015 sebanyak 115 orang dengan menggunakan rumus Solvin dan tingkat kesalahan pengambilan sampel yang ditolerir ditetapkan 5\% maka jumlah sampel dalam penelitian diperoleh 53 orang calon mahasiswa.

Teknik pengumpulan data dilakukan dengan menggunakan kuesioner yang disusun dalam bentuk pernyataan dengan mengikuti Skala Likert. Selanjutnya pengujuan instrument penelitian dilakukan berdasarkan Uji Validitas dan Uji Reliabilitas. Untuk menjawab pertanyaan kualiatatif di gunakan metode observasi, wawancara serta studi dokumentasi.

Teknik analisis data dalam penelitian ini digunakan dua metode untuk penelitian kualitatif digunakan tehnik triangulasi data. 
Teknik analisis data yang digunakan dalam penelitian kualitatif yaitu dengan menggunakan teknik triangulasi data. Menurut Bungin (2013), dengan menggunakan strategi. Pengecekan derajat kepercayaan penemuan hasil penelitian beberapa teknik pengumpulan data, pengecekan beberapa sumber data dengan metode yang sama. Triagulasi data untuk melakukan pengecekan terhadap penggunaan metode pengumpulan data. apakah informasi yang didapat dengan metode wawancara sama dengan metode observasi, begitu juga sebaliknya.

Sedangkan penelitian kuantitatif yaitu mendeskrifsikan efektifitas strategi promosi yang telah dilakukan digunakan tehnik analisi regresi berganda, Uji F (serempak), dan Uji T (parsial) merupakan alat uji statistik yang digunakan untuk mengetahui secara serempak dan secara parsial pengaruvariabel independen terhadap variabel dipenden pada tingkat kepercayaan $95 \% \quad(\alpha=0,05)$. Data yang diperoleh dalam penelitian ini dengan menggunakan data statistik dengan menggunakan SPSS 20.

\section{HASIL PENELITIAN DAN PEMBAHASAN Karakteristik Sampel}

Jumlah subjek yang berjenis kelamin laki-laki lebih tinggi sebanyak 42 orang (79,24\%) dibanding subjek berjenis kelamin perempuan sebanyak 11 orang (20,76\%).
Sedangkan diperoleh gambaran bahwa jumlah subjek yang terbesar berasal dari program studi Pendidikan Olahraga sebanyak 23 orang (43,39\%), kemudian Ekonomi Manajemen 18 orang $(33,96)$, dan Pendidikan Bahasa Inggris 12 orang (22,65). Sedangkan untuk menjawab pertanyaan kualitatif maka Adapun karakteristik dalam pemilihan informan yaitu: untuk informan adalah orang yang mengetahui prosedur strategi promosi secara luas dan mengkoordinir secara langsung proses promosi tersebut.

Subjek AR mengatakan bahwa melaksanakan kegiatan promosi iklan tim promosi melakukan pembuatan baliho, spanduk, leaflet, poster, brosur, branding car, umbul-umbul, dan stiker yang mereka pasang ditempat strategis. adapun beberapa jenis alat promosi tersebut ada yang mereka buat sendiri di lab. praktek cetak, hal ini dilakukan untuk melatih keterampilan darimahasiswa dan menghemat pengeluaran anggaran yang cukup besar. Selain itu tim promosi juga memasang iklan pada media cetak dan media elektronik walaupun dalam jumlah terbatas.

Adapun hambatan-hambatan yang diperoleh selama melakukan kegiatan promosi Iklah adalah dana promosi yang masih kurang yang diberikan oleh kantor pusat khusunya untuk kegiatan periklanan.

Subjek AS mengatakan bahwa dalam melaksanakan kegiatan personal selling tim 
promosi melakukan kunjungan atau sosialisasi ke sekolah-sekolah seperti SMU/SMK Negeri dan swasta. Biasanya tim promosi terdiri dari 2 sampai 3 orang yang bertugas untuk memberikan informasi secara langsung kepada pihak sekolah dan para siswa kelas 3 (tiga) yang akan mengikuti UAN.

Adapun faktor-faktor penghambat yang pada kegiatan personal selling adalah kurangnya SDM yang mampu berkomunikasi dengan baik dalam memberikan informasi secara langsung kepada masyarakat khususnya siswa yang akan segera mengikuti UAN.

Subjek AA mengatakan bahwa dalam melaksanakan kegiatan publisitas tim membuat kegiatan workshop atau event di kampus dan di luar kampus kemudian mengundang wartawan dari media cetak untuk meliput kegiatan tersebut. Selain itu tim promosi memanfaatkan media internet melalui jejaring sosial FB dan Website untuk membagikan gambar atau foto kegiatan workshop dan event yang telah mereka lakukan kepada pengguna jejaring sosial yang lain. Hal ini diharapkan dapat membuat citra kampus baik di masyarakat,subjek juga mengatakan bahwa faktor penghambat dalam kegiatan publisitas selama ini adalah masalah dana yang dirasa belum mencukupi untuk melaksankan kegiatan publisitas secara maksimal, hal lain yang juga dirasakan menjadi kendala adalah kurangnya SDM pada bagian kehumasan yang dapat merancang sebuah perencanaan komunikasi yang baik.

Subjek EH mengatakan bahwa dalam melaksanakan kegiatan word of mouth selain melibatkan tim promosi kegiatan ini juga melibatkan seluruh pegawai dan mahasiswa Univeristas PGRI Palembang untuk menyebarluaskan informasi yang positif mengenai kampus kepada masyarakat luas disekitar mereka seperti keluarga, teman, tetangga, ataupun orang yang mereka kenal, dalam kegiatan ini diharapkan orang yang mendapat informasi akan tertarik dan menyebarluaskan kembali informasi tersebut kepada orang lain. Subjek mengatakan bahwa faktor yang menjadi kendala dalam kegiatan word of mouth adalah masalah yang bersifat internal, yaitu kurang baik dan harmonisnya hubungan komunikasi interpersonal antar sesama pegawai, hal ini menyebabkan komitmen untuk menyebarluaskan informasi melalui word of mouth masih terkesan setengah-setengah serta menjadi cerminan yang kurang baik dari para mahasiswa terhadap kinerja organisasi Universitas PGRI Palembang.

\section{Analisis Uji Hipotesis}

Berdasarkan data penelitian yang dikumpulkankan baik untuk variable terikat (Y) maupun variable bebas $(\mathrm{X} 1, \mathrm{X} 2, \mathrm{X} 3, \mathrm{X} 4)$ yang diolah dengan menggunakan bantuan 
program SPSS 20.0, maka dipeoleh hasil perhitungan regresi linear berganda sebagai berikut:

Hasil pengujian statistic dengan metode uji $\mathrm{F}$ (serempak), di mana tingkat signifikant yang diperoleh lebih kecil yakni 0,0000 dari standar signifikan yakni 5\% atau 0,05 dan perbandingan antara Fhitung dan Ftabel, dimana Fhitung sebesar 22,873 lebih besar dari Ftabel yakni 2,565, maka dapat disimpulkan bahwa Ha diterima atau strategi promosi memiliki pengaruh yang cukup significant terhadap peningkatan jumlah mahasiswa pada Universitas PGRI Palembang.

Sedangkan untuk Uji T (parsial) iklan, tingkat signifikant yang diperoleh 0,005, personal selling sebesar 0,6 , dan word of Moutf 0,04 ini sesuai dari standar signifikan, sedangkan Publisitas 0,68 sangat jauh dari standar signifikan yakni $5 \%$ atau 0,05 . Perbandingan antara thitung dan ttabel, dimana thitung Iklan sebesar 2,942, Personal Selling sebesar 2,741, Word of Mouth 3,047lebih besardari ttabel 2,010, sedangkan Publisitas sebesar 1,867 lebih kecil dari ttabel 2,010 maka dapat disimpulkan bahwa Iklan, Personal Selling, dan Word of Mouth memberikan pengaruh signifikan terhadap jumlah mahasiswa, sementara Publisitas tidak memberikan pengaruh yang signifikan terhadap jumlah mahasiswa.
Penelitian ini menunjukkan bahwa dalam melakukan kegiatan promosi Univeristas PGRI Palembang melakukan 4 (empat) bauran promosi, yaitu Iklan, Personal Selling, Publisitas, dan Word of Mouth, dimana Iklan adalah promosi yang paling berpengaruh dan Publisitas adalah promosi yang tidak berpengaruh dalam peningkatan jumlah mahasiswa.

Dimensi Iklan dilakukan dengan pembuatan baliho, spanduk, leaflet, poster, brosur,

branding car, umbul-umbul, dan stiker yang mereka pasang ditempat strategis. Seperti pinggir jalan, sekitar lingkungan sekolah seperti SMU/SMK negeri dan swasta dan tempat keramain lainnya.Senada dengan Cangara (2013), mengatakan bahwa iklan adalah cara promosi yang sering digunakan dalam pemasaran komersil. Iklan dapat dilakukan melalui media, antara lain: Media elektronik (televisi, radio, film, bioskop, internet); Media cetak (surat kabar, majalah, bulletin); Media luar ruangan ( papan reklame, electronic board yang dipsasang di pinggirpinggir jalan yang bergerak secara elektronik, baliho, iklan pohon, spanduk, poster dan lainlain).

Dimensi Personal Selling dilakukan dengan cara kunjungan atau sosialisasi ke sekolah-sekolah seperti SMU/SMK Negeri dan swasta. Biasanya tim promosi terdiri dari 2 
sampai 3 orang yang bertugas untuk memberikan informasi secara langsung kepada pihak sekolah dan para siswa kelas 3 (tiga) yang akan mengikuti UAN, Swastha (2002), mengatakan bahwa Personal selling adalah interaksi antar individu, saling bertemu muka yang dirujukan untuk menciptakan, memperbaiki, menguasai atau mempertahankan hubungan pertukaran yang saling menguntungkan dengan pihak lain.

Dimensi Publisitas dilakukan dengan cara membuat kegiatan workshop atau event di kampus dan di luar kampus kemudian mengundang wartawan dari media cetak untuk meliput kegiatan tersebut. Selain itu tim promosi memanfaatkan media internet melalui jejaring sosial FB dan Website untuk membagikan gambar atau foto kegiatan workshop dan event yang telah mereka lakukan kepada pengguna jejaring sosial yang lain. Hal ini diharapkan dapat membuat citra kampus baik di masyarakat.Sesuai dengan pendapat dari Swastha (2002), Publisitas adalah "Sejumlah informasi tentang seseorang, barang, atau organisasi yang disebar luaskan ke masyarakat melalui media tanpa dipungut biaya, atau tanpa pengawasan dari sponsor".

Dimensi Word of Mouth dilakukan dengan cara melibatkan seluruh jajaran pegawai dan mahasiswa Universitas PGRI Palembanguntuk menyebarluaskan informasi yang positif mengenai kampus kepada masyarakat luas disekitar mereka seperti keluarga, teman, tetangga, ataupun orang yang mereka kenal, dalam kegiatan ini diharapkan orang yang mendapat informasi akan tertarik dan menyebarluaskan kembali informasi yang telah diterima tersebut kepada orang lain. Frisbee et al (2000), juga menyebutkan bahwa kelompok teman sebaya dapat menjadi salah satu bentuk pemasaran yang paling efektif. Melihat usia siswa SMU, teman sebaya merupakan salah satu faktor yang paling memiliki pengaruh penting dalam pengambilan keputusan.

Hasil analisis data yang diperoleh peneliti dengan menggunakan metode penelitian kuantitatif untuk menjawab rumusan masalah. Pertama untuk melihat pengaruh secara keseluruhan diperoleh Fhitung sebesar 22,873 dengan tingkat significant 0.000 oleh karena nilai Fhitung lebih besar dari Ftabel yaitu 2,565 maka Ho ditolak dan Ha diterima. Hal ini menunjukkan iklan, personal selling, publisitas, dan word of mouth secara bersamasama berpengaruh signifikant terhadap peningkatan jumlah mahasiswa pada Universitas PGRI Palembang. Besaran pengaruhnya secara bersama-sama sebesar $65,6 \%$ dan variebel lain yang tidak diteliti oleh peneliti yang dapat memberikan kontribusi sebesar 34,4\% (100\%-65,6).

Dimensi Iklan berpengaruh paling signifikan. Hal ini dapat dilihat bahwa 
besarnya nilai thitung adalah sebesar 2,942 dengan tingkat signifikant 0,05 sesuai standar $\alpha=0,05$, dan thitung lebih besar dari ttabel yaitu 2,010 yang artinya Ho ditolak dan $\mathrm{Ha}$ diterima, besaran pengaruhnya adalah $34,3 \%$ dari dimensi yang lain,. Hal ini juga didukung oleh penelitian dari Aliyah (2010), "Strategi Promosi Fakultas Dakwah Universitas Universitas Negeri Sunan Kalijaga Dalam Meningkatkan Jumlah Mahasiswa Periode 2009-2010", dalam penelitian ini di jelaskan bahwa iklan merupakan variabel yang paling dominan dalam mempengaruhi jumlah mahasiswa. Dimana dalam melakukan bauran iklan fakultas Dakwah UIN Sunan Kalijaga menggunakan media elektronik terdiri dari Televisi, radio, dan Internet, serta media cetak melalui spanduk, banner, brosur, spanduk, dan leaflet.

Dimensi Personal Selling berpengaruh cukup signifikan. Hal ini dapat dilihat bahwa besarnya nilai thitung adalah sebesar 2,741 lebih besar dari ttabel yaitu 2,010 yang artinya Ho ditolak dan Ha diterima. Besarannya pengaruhnya adalah $27,3 \%$ dari dimensi yang lain. Senada dengan pendapat dari Gitosudarmo (2004), Bahwa kontak langsung antara penjual dan calon konsumen dapat mempengaruhi secara lebih intensif para konsumennya karena dalam hal ini penjual dapat mengetahui keinginan dan selera konsumen, dengan demikian penjual dapat menyesuaikan cara pendekatan atau komunikasi dengan konsumen secara tepat dan sesuai.

Dimensi Publisitas berpengaruh secara tidak signifikan. Hal ini dapat dilihat bahwa besarnya nilai thitung adalah sebesar 1.867 dengan tingkat signifikant 0,68 jauh di atas $\alpha=0,05$, dan thitung lebih kecil dari ttabel yaitu 2,010 yang artinya $\mathrm{Ho}$ diterima dan $\mathrm{Ha}$ ditolak. Berbeda dengan penelitian sebelumnya dari Tierab dan Mulawarman (2009), “ Strategi Promosi Universitas Swasta dalam Menarik Mahasiswa Baru" studi kasus pada STMIK Bina Nusantara Jakarta, pada penelitian itu mengatakan bahwa Corporate Marketing Communication STIMIK Bina Nusantara dapat mengadakan acaranya sendiri, yaitu seperti seperti seminar, workshop, maupun pameran yang menarik. Dalam event media meliput mengenai STIMIK Bina Nusantara dan menjadikan berita tersebut sebagai bagian dari promosi dan berhasil mencapai target yang di rencanakan sebelumnya.

Dimensi word of mouth berpengaruh secara signifikan. Hal ini dapat dilihat bahwa besarnya nilai thitung adalah sebesar 3,047 dengan tingkat signifikant 0,04 di bawah $\alpha=0,05$, dan thitung lebih besar dari ttabel yaitu 2,010 yang artinya Ho ditolak dan $\mathrm{Ha}$ diterima. Besarnya pengaruh adalah $29,1 \%$. Sesuai dengan pendapat dari Ristiyanti dan 
Ihalauw (2005), "Dalam faktor-faktor yang mempengaruhi minat beli, ditemukan adanya faktor eksternal yang di dalamnya terdapat kelompok acuan sebagai pencipta komunikasi dari mulut ke mulut, kelompok acuan tersebut terdiri dari keluarga, teman, tetangga, kelompok kerja dan kelompok formal, yang nantinya mereka akan memberikan pengaruh kepada orang lain terhadap suatu produk baik itu bersifat negatif maupun bersifat positif."

Faktor-faktor Penghambat Kegiatan Promosi adalah Dana Kegiatan Promosi yang diberikan untuk operasional kegiatan dirasa belum mencukupi untuk melaksanakan kegiatan promosi Iklan, Personal Selling, Publisitas, dan Word of Mouth secara maksimal guna mendapatkan hasil sesuai yang diharapkan. Sesuai dengan pendapat dari Irawan (1990), mengatakan bahwa "ada beberapa faktor yang mempengaruhi penentuan terbaik dari variabel - variabel promotion mix, salah satu faktor tersebuat adalah anggaran atau dana promosi, bila perusahaan/lembaga memiliki dana promosi yang besar, maka peluang untuk menggunakan iklan bersifat nasional juga besar."

Belum adanya sumber daya manusia dalam bidang ilmu komunikasi pada tim promosi khusunya dalam bidang Kehumasan, ini menyebabkan perencanaan komunikasi pemasaran untuk kegiatan promosi tidak tersusun secara baik dan maksimal sehingga peningkatan jumlah mahasiswa belum sesuai dengan apa yang diharapkan. Hubungan komunikasi interpersonal antar sesama pegawai yang kurang harmonis, hal ini menyebabkan komitmen untuk mendukung seluruh kegiatan promosi masih terkesan setengah-setengah. Kriyantono (2008), mengatakan bahwa tugas komunikasi sebuah lembaga pendidikan salah satunya adalah membangun citra korporat, dimana tugas komunikasi ini dilaksanakan oleh seluruh unsur lembaga (karyawan dan pimpinan) ikut andil dalam pembentukan citra ini, baik disadari atau tidak. Citra positif merupakan langkah penting menggapai reputasi lembaga di mata khalayak.

\section{KESIMPULAN}

Dalam melakukan strategi promosi Universitas PGRI Palembang menggunakan (empat) bauran promosi, yaitu Iklan Personal Selling, Publisitas, dan Word o Mouth. Dimensi iklan (advertising) adalah merupakan dimensi strategi promosi yang paling berpengaruh terhadap peningkatan jumlah mahasiswa pada Universitas PGRI Palembang, sedangkan yang tidak memiliki pengaruh yang signifikant adalah publisitas. Secara keseluruhan variabel promosi memiliki pengaruh yang signifikant terhadap peningkatan jumlah mahasiswa pada Universitas PGRI Palembang. Kendala kendala yang ditemui selama kegiatan promosi 
dilakukan adalah minimnya dana yang diberikan untuk seluruh kegiatan promosi yang dilakukan, sehingga kegiatan promosi kurang memberikan kontribusi yang maksimal terhadap peningkatan jumlah mahasiswa, kurangnya SDM pada bidang komunikasi khususnya dalam merancang perencanaan kegiatan promosi yang baik, dan komunikasi interpersonal yang kurang baik antar sesama pegawai. Oleh karena itu Strategi promosi yang telah dilakukan seperti Iklan, Word Of Mouth, Publisitas, Dan Personal Selling harus lebih dikembangkan, selanjutnya Tim Promosi Universitas PGRI Palembanghendaknya merencanakan anggaran promosi yang efektif dan efisien untuk setiap kegiatan promosi, serta lembaga Humas harus difungsikan sesuai dengan fungsinya dan mengembangkan SDM khusunya dalam bidang ilmu komunikasi.

\section{DAFTAR PUSTAKA}

Aliyah Ning. (2010). Strategi Promosi Fakultas Dakwah Universitas Islam Negeri Sunan Kalijaga Dalam Meningkatkan Jumlah Mahasiswa Periode 2009-2010. (Jurnal Online), http://digilib.uin-suka.ac.id

Bungin Burhan. (2013). Metode Penelitian Kuantitatif, Kencana Prenada Media Group,

Cangara Hafied. (2013). Perencanaan dan strategi komunikasi, Rajawali Pers.
Frisbee et al .(2000). Ray E. Abstract: Published: Athens, Georgia: American Vocational Education Research Association.

Gitosudarmo Indriyo.(2004). Marketing dan Kasus-kasus Pilihan, Penerbit Centre of Academic Publishing Service (CAPS).

Irawan (1990). Manajemen Pemasaran Modern.Liberty Yogyakarta

Lupiyoadi, R. (2001). Manajemen Pemasaran Jasa: Teori dan Praktek. Jakarta: Penerbit Salemba Empat Jakarta.

Kriyantono Rachmat. (2008). Teknik Praktis

Riset Komunikasi. Kencana Prenada Media Group. Jakarta.

Ristiyanti Prasetijo dan Ihalauw, Jhon J.O.I. (2005). Perilaku Konsumen. Yogyakarta: Penerbit Andi.

Swastha. (2002). Manajemen Pemasaran. Edisi Kedua. Cetakan Kedelapan. Jakarta: Penerbit Liberty.

Sutabri Tata. (2007). artikel komersiliasi pendidikan tinggi , http:// www. wikimu.com/News/Print.aspx?id=2678

Tierab P. Fhebrian dan Mulawarman Enrico. (2009). Strategi Promosi Universitas Swasta dalam Menarik Minat Mahasiswa baru Jakarta STIMIK Bina Nusantara

Yuliani, T., \& Kristiawan, M. (2017). Peran Kepemimpinan Kepala Sekolah dalam Membina Kompetensi Sosial (Pelayanan Prima) Tenaga Administrasi Sekolah. Jurnal Manajemen, Kepemimpinan, dan Supervisi Pendidikan, 1(2). 